\title{
Congress asks "why Japan?"
}

\section{Washington}

MASSACHUSETTS Institute of Technology's Industrial Liason Program found itself at the centre of a storm last week as a Congressional subcomittee probed the way the programme provides advance access for foreign companies to research programmes paid for by US federal funds.

About a half of the members of the liaison programme are foreign and, for a yearly fee of just $\$ 10,000-50,000$, MIT programme officers help give easy access to $\$ 300$ million a year of research, most of it paid for by the government.

The hearing by the Government Operations subcommittee on Human Resources and Intergovernmental Relations examined many examples of the conflicts of interest that have "followed private industry funds into the university" as subcommittee chairman Ted Weiss (Democrat, New York) put it. But in an often fractious hearing the subcommittee's strongest censure was reserved for MIT's Industrial Liaison Programme (ILP).

According to David Noble, a professor of history at Drexel University, MIT has portrayed the programme as a model for the transfer of the fruits of governmentfunded research from universities to US industry. But, he says, MIT has failed to say that a quarter of the members are

\section{Biomedical bugs \\ Washington}

THE bargain sale of US-financed research data to Japan was not the only conflict of interest to exercise the Human Resources and Intergovernmental Relations subcommittee hearing last week.

Biomedical researchers were seen as particularly likely to suffer conflicting interests, given the huge sums of money from pharmaceutical companies that supplement federal funds for drug developent and clinical trials.

Commercialization "has been more aggressive, more brazen, and more experimental than other disciplines", according to Sheldon Krimsky, a professor of urban and environmental policy at Tufts University. He claimed that there is evidence that refusal to share data and biological materials is increasing, even among scientists working for the federal government, implying that "public funds are being used to support propietary knowledge".

Krimsky believes that new relations between universities and industry, such as Boston University's controversial \$25 million investment in the Seragen biotechnology company, provide a "recipe for conflict of interest". According to his own survey, 45 per cent of Harvard University's biomedical faculty now have formal affiliations with 36 different biotechnology companies.

A.A.
Japanese and that it maintains an "overseas sales office in downtown Tokyo".

Each company joining the programme is given a liason officer who will alert it to programmes, patents and research of particular interest, supply preprints, arrange telephone contacts and find staff to serve as consultants. Noble claimed that this system, and similar programmes at many other universities, including Stanford, had the effect of "subsidizing foreign competition and productivity with taxpayer supported research" in "the interest of a short-term gain".

In a series of frequently interrupted explanations, Paul Gray, president of MIT, fought to play down the importance of the programme, pointing out that all MIT research is eventually published and anyone, whether a member of ILP or not, is free to contact MIT staff.

Congressional subcommittee members found Gray's explanation hard to square with the promises in ILP's advertising brochure and the rewards for participation in the programme given to MIT staff. Ten per cent of the programme revenue is distributed among the staff, with points given for telephone contacts, letters, looking after visitors, going out to factories and laboratories, and so on. And Weiss did not see why US companies should "pay again" for access to research already paid for by their tax dollars.

Eric Bloch, director of the National Science Foundation (NSF), put up a better-received defence of MIT. Bloch argued that basic research results should be freely available; the real problem is not that MIT provides open access to everyone, but that Japan does not provide equal access to its own research. Access is " 50 to 1" in favour of the Japanese, he said. Weiss concluded that it might be better for MIT to stop "soliciting" in Japan until problems of access were solved.

\section{Tokyo}

MEMBers of the staff of MIT's Tokyo Office repeatedly refused to describe their activities last week, claiming that their director was unavailable for comment. But according to a report prepared in 1986 by the NSF's Tokyo Office, 52 Japanese companies are members of ILP, including such giants as Hitachi, NEC, Mitsubishi and Toyota.

The director of the MIT Tokyo Office is quoted as saying that Japanese companies join the programme because they are "searching for new areas or fields" in which to become involved or because they may "need help and advice" with a new research facility.

The report says that, in 1983-84, 800 people from Japanese member companies attended 25 ILP seminars held in Japan.

\section{Assigning blame before the change}

Washington

TROPICAL rain forest may be burning, but Latin American nations do not want to be blamed for the greenhouse effect or other global environmental problems.

Speaking at a forum organized by the Agency for International Development earlier this month, Alvaro Umana, Minister of Natural Resources, Energy and Mines from Costa Rica accused developed nations of making the global environment into "a north-south confrontation" and asked "what moral authority do the developed nations have?" Not very much, according to figures from the Boston-based Conservation Law International and World Resources Institute.

US carbon dioxide emissions totalled 1,200 million tons of carbon in 1985, compared to just $\mathbf{2 8 0}$ million tons for the whole of Latin America. Even Japan produced only a little over 200 million tons, and Britain, West Germany and France all produced slightly less. Of the US emissions, 35 per cent were produced in electricity generation and over a quarter by automobiles. The United States has the lowest gasoline prices and the least efficient automoblies of any of the developed countries.

A Global Warming Prevention Act sponsored by Representative Claudine Schneider (Democrat, Rhode Island) contains a "gas-guzzler" automobile tax among its many energy-saving measures.

Alun Anderson

And, on the average, at least one MIT professor visits Japan each week under the programme.

US companies do not enjoy comparable access to Japanese research because much of the research of interest is done in Japan's private sector. The US-Japan science and technology agreement signed last year is intended to improve US access.

But new Japanese government fellowship programmes introduced in response to the agreement are intended for research in government laboratories and universities. US researchers can carry out research in Japanese companies under NSF programmes, according to Alexander DeAngelis, head of NSF's Tokyo office, but only a handful have taken up the opportunity.

Some US companies are beginning to realize the importance of tapping Japan's excellence in research and development. Notable among them is Eastman Kodak, which last October opened a $¥ 10,000$ million (\$70 million) research and development centre in Japan which is staffed by foreign and Japanese researchers. Such private-sector initiatives may help redress the imbalance in access to research in the two countries.

David Swinbanks 